\title{
Strategic planning and experience in the construction of the OPV Project for the Chilean Navy
}

Planificación estrategica experiencia en la construcción del Proyecto OPV para la Armada de Chile

DOI: https://doi.org/10.25043/19098642.168

Pedro Andrés Gómez Salazar ${ }^{1}$

\begin{abstract}
ASMAR's shipbuilding policy indicates that this activity will be centered and dimensioned on primarily serving the requirements of the Chilean Navy and the State. The correct use of the information is fundamental in the evolution of the projects. By applying this knowledge and evaluation criteria to the strategy of the Naval Construction Management, it will contribute in future projects by improving the planning levels obtaining more detailed, efficient and effective results. Below we present the experience in the strategic planning for the construction of the OPV4 project, Cabo Odger ("Marine Lance Corporal Odger") for the Chilean Navy.

"We want all our shipping clients to recognize us as a serious shipyard, with dedicated commitment and technical quality, and we have used ingenuity and experience to solve problems that we have faced. However, we must not fall into the temptation to rest on our laurels, on the contrary, we have the obligation to continue on this path of commitment with our daily work, and to meet our deadlines" .

Today, shipbuilding is defined as a highly complex industry, that is highly competitive with elevated costs. The goal is to extract the most important contents and work with real, efficient and effective information, so that each construction process is not affected by external agents. There are three differentiating factors that make a shipyard more competitive and improve its production processes, resulting in a reduction of work time and, therefore, a reduction of costs; these are: the construction strategy, strategic planning and logistics. ASMAR has the technical and technological capacity to integrate various elements into its workshops in the stage prior to assembly. This process marks an important step between the construction strategy and the project planning.
\end{abstract}

Key words: Strategy, Planning, Logistics, Production.

\section{Resumen}

La política de construcción naval de ASMAR, indica que esta actividad estará centrada y dimensionada para atender prioritariamente los requerimientos de la Armada y del Estado de Chile. El correcto uso de la información es clave en la evolución de los proyectos, dicho conocimiento y criterios de evaluación fueron aplicados a la estrategia constructiva de la gerencia de Construcción Naval, la cual contribuirá en próximos proyectos a mejorar los niveles de planificación obteniendo como resultado niveles para producción más detallados, más eficientes y más eficaces. A continuación, se presenta la experiencia en la planificación estratégica para la construcción del proyecto OPV4, "Cabo Odger" para la Armada de Chile.

"Somos todos nosotros los que permitimos que nuestros clientes navieros nos reconozcan como un astillero serio, de compromiso y calidad técnica, habiendo utilizado muchas veces el ingenio y la experiencia para enfrentar y solucionar los problemas que se han enfrentado. Sin embargo, no debemos caer en la tentación de sentirnos cumplidos con lo que hacemos, por el contrario, tenemos la obligación de continuar en este camino de compromiso con nuestros trabajos diarios, sobre todo con el trabajo bien hecho a la primera y el cumplimiento de plazos".

Hoy en día, la construcción naval se define como una industria de síntesis, es decir, busca extraer los contenidos más importantes y trabajar con información verídica, eficiente y eficaz, de tal manera que cada proceso de construcción no se vean afectados por agentes externos. Existen tres factores diferenciadores que hacen a un astillero más competitivo y que mejoran sus procesos productivos, consiguen una reducción en sus tiempos de trabajo y por lo tanto, logran una reducción de costos, estos son; la estrategia constructiva, la planificación estratégica y la logística. ASMAR y su astillero constructor, posee la capacidad técnica y tecnológica de integrar en sus maestranzas diversos elementos en la etapa previa al montaje en grada, es justamente este proceso que marca un quiebre trascendental entre la estrategia constructiva y la planificación de un proyecto.

Palabras claves: Estrategia, planeación, logística, producción.

Date Received: January $4^{\text {th }} 2017$ - Fecha de recepción: Enero 4 de 2017

Date Accepted: February 28 2017 - Fecha de aceptación: Febrero 28 de 2017

${ }^{1}$ ASMAR Shipbuylding \& Shiprepair company. Talcahuano, Chile. Email: pgomezs@asmar.cl 


\section{Introduction}

Shipbuilding is defined as a highly complex industry, that is very competitive with elevated costs (Depto. de Información de la división de Productos Industriales y Tecnologia, 2011). The goal is to extract the most important contents and work with real, efficient and effective information, so that each construction process is not affected by external agents.

There are three differentiating factors that make a shipyard more competitive and improve its production processes, resulting in a reduction of work time and, therefore, a reduction of costs; these are:

- The Construction Strategy (C.S. ${ }^{1}$ )

- Strategic Planning

- Logistics

ASMAR has the technical and technological capacity to integrate various elements into its workshops in the stage prior to assembly. This process marks an important step between the construction strategy and the project planning.

\section{General Objective}

The objective is to plan, elaborate and disseminate the different stages of the construction of naval artifacts and other items in an efficient manner.

\section{Specific Objective}

The Manual of Construction Strategy (C.S.M. ${ }^{2}$ ) is a production tool. It seeks to guide and deliver clear and relevant information on the construction of the different units of the Asmar shipyards.

\section{Utility, benefits and importance}

Construction Strategies can cover the most overarching aspects to the smallest details,

1 Construction Strategy.

2 Construction Strategy Manual but always with the purpose of delimiting the fundamental aspects of any project. Currently, due to the diversity of the administrative and productive processes, the administration of projects must be handled with clear and specific information. Poor management of this information can lead to errors in the correct development of a project, directly affecting the degree of progress of the different construction stages.

The Construction Strategy will include the general aspects of the shipyard, considering all the limitations present when creating the manual. However, it should be defined in a specific and individual way for each product to be built. Through the Construction Strategy Management it will be possible to plan, direct and control all the critical activities that affect the productive process of each unit, so it is important that this be defined from the initial phases of any shipbuilding project.

\section{Use of information}

The Construction Strategy Management is a document oriented to the delivery of real information to the different production workshops, which depend directly on the Shipbuilding management.

The correct use of this information is subject to the distribution of this document, of the adaptability and acceptance criteria by the shipbuilding management workshops, which is why this new stage begins by training the personnel directly involved in the Construction of the product. It will be important to carry out this introduction to the workshops, every time a new project is started, as each construction will have different ways to be approached. (Traba \& López, 2004/2006).

The Construction Strategy Management. is composed of the three main parts, they are:

\section{Generalities}

This section explains in a concise way the location of the product to be developed, in addition to a small introduction and additional content, covering the 
position, space and personnel of the workshops of the naval construction management.

\section{Assembly Sequences}

This section details the assembly sequences of the different blocks, either at the structural level with the definition of the positioning of the pipes in a sequential and logical way, in addition to referring to the main equipment contained in the block, in order that the development of the construction of the unit is as harmonious as possible, so that it does not affect the planning of the project.

\section{References}

This part contains all the reference information that was used to prepare the manual, as well as a checklist of the different systems identified with the FORAN ${ }^{\oplus 3}$ nomenclature. The latter is so that supervisors and workshop engineers are able to quickly identify and isolate systems, bases or equipment, according to requirements.

\section{Differential Aspects}

The Construction Strategy section was created in May 2009 with the objective of establishing the methodology for developing, disseminating and updating the Construction Strategy of shipbuilding projects. This was applied directly and transferred to the Construction Strategy manuals, which were elaborated at the area level. The distribution of these manuals to the workshops was only through the registration in the computer network of the shipyard, which meant that one of its main objectives, to disseminate the information, was not complied with.

The new methodology proposed by the Construction Strategy Management, has the same objective established by the Construction Strategy section since its creation, nevertheless there is a significant change in the information embodied in the new manuals.

CAD/CAM system, 3D modeling, SENER Company
With this approach the goal is for the Construction Strategy to mobilize all the activities of the program and be the main actor in decision making in the project and production. (Fig. 1)

Fig. 1.

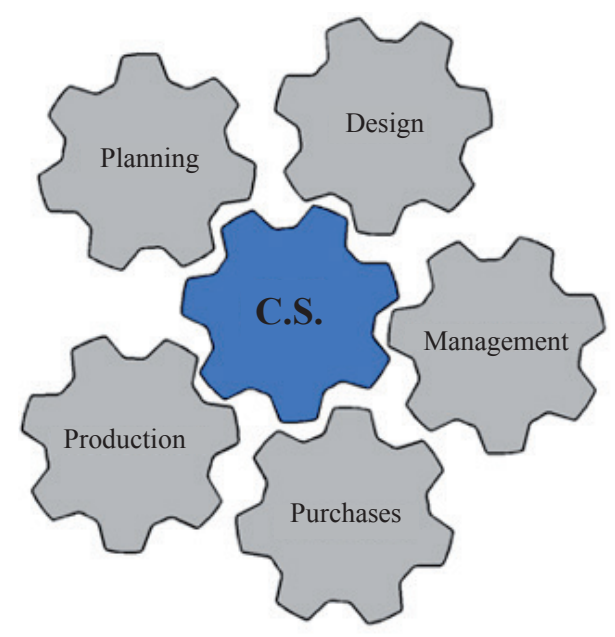

In this new version of the Construction Strategy it was decided to work at the block level, which means to change the information horizon, going from macro to micro format. This new Construction Strategy will have a greater level of construction details with the aim of facilitating and improving the planning and the release of the works to the shipyard workshops.

\section{Evaluating criteria}

In view of the different specific objectives determined by Construction Strategy and for the expected learnings, the evaluation criteria are proposed and, from them, questions are suggested and prepared so that the Naval Construction workshops can evaluate the manuals and give us guidelines for our continuous improvement. It should be noted and remembered that the main objective of these Construction Strategy manuals is to meet the needs of our customers, the project and the production of the shipyard.

The criteria indicated are:

- TO VERIFY to what extent the workshops have internalized the concepts and proposals 
of the Construction Strategy Management

- TO OBSERVE how workers implement the concepts of the main and secondary actions proposed in the Construction Strategy Management

- DETERMINING the degree of adoption and internalization by production personnel with respect to the proposals of the Construction Strategy Management

\section{Management of materials and production planning}

From the perspective of the optimization of decision making, a production plan must balance the fulfillment of three commonly conflicting objectives: Increasing the satisfaction of demand, reducing inventory levels and maximizing production efficiency (reducing the time and cost of set-up). These objectives are mainly associated, but not exclusively so, to the priorities of the commercial, financial and production areas, respectively.

The materials management systems of the different construction processes ensure that the materials and products are available in the correct amount and at the time required for the shipyard and the project. There are several methods of materials management. The best system for long-term projects, such as shipbuilding, is the $\mathrm{MRP}^{4}$ system (Fig. 2), which operates on the basis of material requirements planning and operates with a "push" ${ }^{5}$ system philosophy. The components must be supplied before being required by the different shipbuilding workshops (Fig. 3)

\section{Planning Levels for Production}

The planning basically consists of the previous analysis of the requirements of the client that are all proposed in the high level requirements. Each of the works are structured in different stages, the estimation, analysis for the technical feasibility, terms and resources, and the programming is

\footnotetext{
4 Materials Requirement Planning

5 Planned Management System
}

Fig. 2. Asmar MRP System, OMEGA

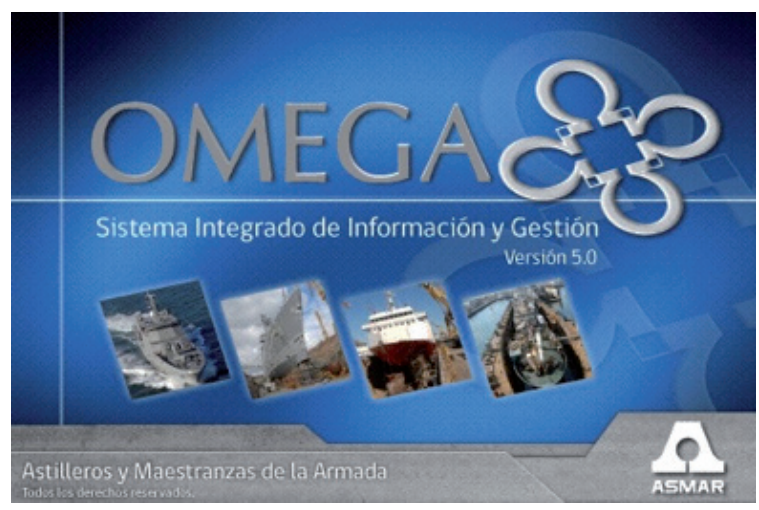

Fig. 3. MRP System benefits, OMEGA

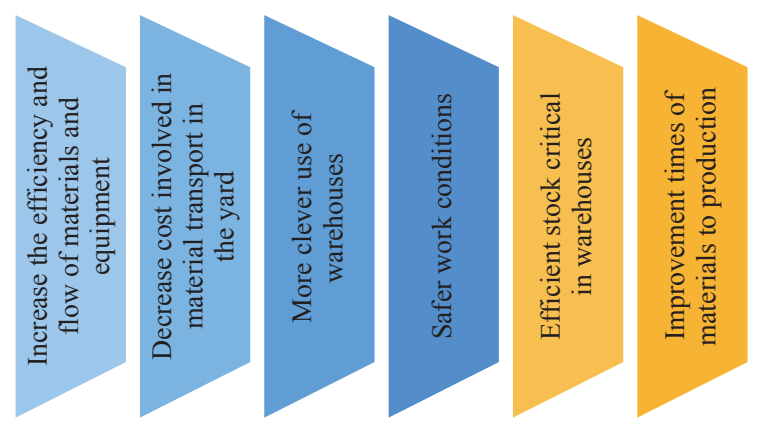

added to them at different levels: Level 1, Level 2, and Level 3. (Fig. 4).

Within the Construction Strategy of each ship, it is necessary to establish objectives that can be controlled, such as indicators of productivity and management of the various production processes.

The main objective of these indicators is to be able to provide the organization with a tool that allows a better control of the productive process, and therefore, better planning, in addition to knowing, through the periodic analysis of these indicators, the degree of effectiveness achieved for each construction.

\section{Level 1}

Program that contains the most important activities of a project. The program is based on a preliminary evaluation of the project and is structured for decision-making by senior management. 
Fig. 4. Systemic planning diagram

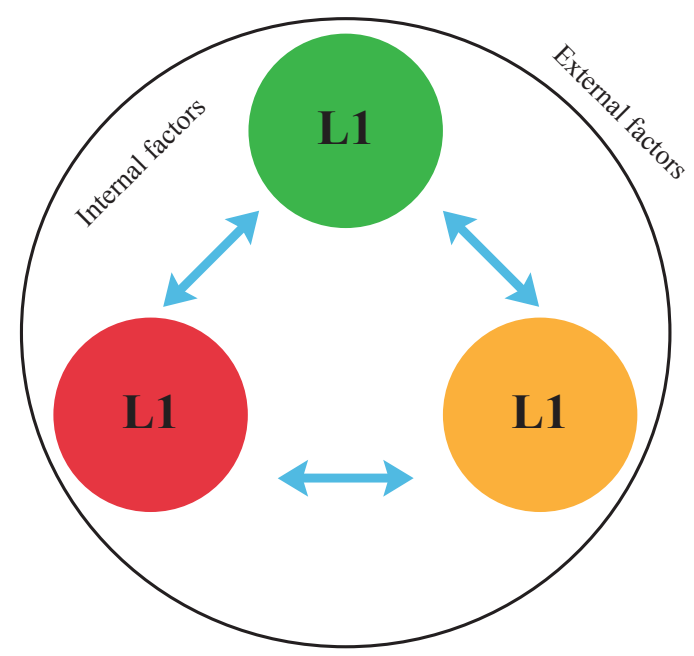

Level 2

Program that contains the activities of the main structure at block level, the team activities at the specialty level, together with the systems and areas to be executed during a project, which is the reference for the third level planning process. Level 2 contains the tasks of the project, is directed at the operational level and as support to production managers, who use it to manage their execution and to coordinate the productive centers that interact in the project.

\section{Level 3}

Program in which the tasks of Level 2 are detailed. Level 3 is aimed at the operator (Shipmasters, Production Engineers, etc.), for the coordination of the activities involved in the execution of the works. This program is prepared by the Production Department in coordination with the production management for highly complex jobs.

Due to the different objectives determined by the Construction Strategy specialty it is necessary that Level 3 planning includes the proposals included in the Construction Strategy Management, as it shows the good results obtained in the development of the Construction of the OPV Cabo Odger ("Marine Lance Corporal Odger"). It is important to mention that this project implements the use of a
Construction Strategy with this level of referencing and details allowing a more efficient construction.

Level 3 Modified according to the Construction Strategy Manuals

Strategic Planning is a management tool that contributes to decision making in the organizations focused on the current task and the path to follow in the future to adapt to the changes and the demands imposed on them by the environment so as to achieve the maximum efficiency and quality of the goods and services provided.

In each project a more detailed programming of the activities and workshops is necessary, in order to fulfill the objectives established by the organization and the project.

Intervention at the current level 3 of production is the beginning of this change, since it allows shipbuilding workshops to improve planning levels, save resources by allocated task, improves the sending of information towards the work fronts, improves the communication of process engineers, the shipbuilding logistics unit, the design department and the Construction Strategy area.

This intervention seeks to organize information by generating an efficient distribution of the workshops and establishing a level 3 according to the requirements of the Construction Strategy, the project and the organization.

\section{Benefits of the Construction Strategy}

There is a variety of literature on the benefits of implementing the Construction Strategy within a shipyard; however, this is not exclusive to companies in this area, as it can be applied to other companies or manufacturing industries.

The correct uses of this tool brings multiple contributions to the project management and planning. The ASMAR Shipyard gained experience through the construction of the OPV 4 project 
Cabo Odger ("Marine Lance Corporal Odger") for the Chilean Navy and the following benefits stand out:

\section{Materials Management}

- Supply of materials according to the plan.

- Efficient management of critical stock.

- Reduced inventory costs.

- Optimization of spaces and storage times.

\section{Planning}

- Maximize and improve demand compliance.

- More detailed planning levels.

- Efficiency in critical equipment warranty times.

\section{Production}

- Supply production requirements efficiently

- Maximize productive efficiency.

- Reduction of the times to dispatch information to the work fronts.

- Ordering the dispatch of information to the workshops.

- Reduction of the accident rate.
- Improvement in the ergonomics in the execution of the works in the workshops.

Fig. 5, represents the difference (in the same months) between the projected advances vs. the scheduled time of the projects OPV3 and OPV4 Cabo Odger ("Marine Lance Corporal Odger") with the latter still in progress.

Although ASMAR has already had experiences with similar projects (OPV 1 and 2), there is evidence that the efficient implementation of strategic planning and the use of knowledge management, specifically the use of the "Construction Strategy Management" tool in the OPV4 project, will contribute to cost savings and meeting final delivery deadlines.

\section{Conclusions}

While making good strategic decisions is one of the organization's major responsibilities, the entire productive chain must be involved in formulating, implementing and evaluating strategies. Participation is essential in order to make sure that all areas are commitment to the required changes.

Fig. 5. Comparative graph between projects OPV3 \& Project OPV Cabo Odger ("Marine Lance Corporal Odger")

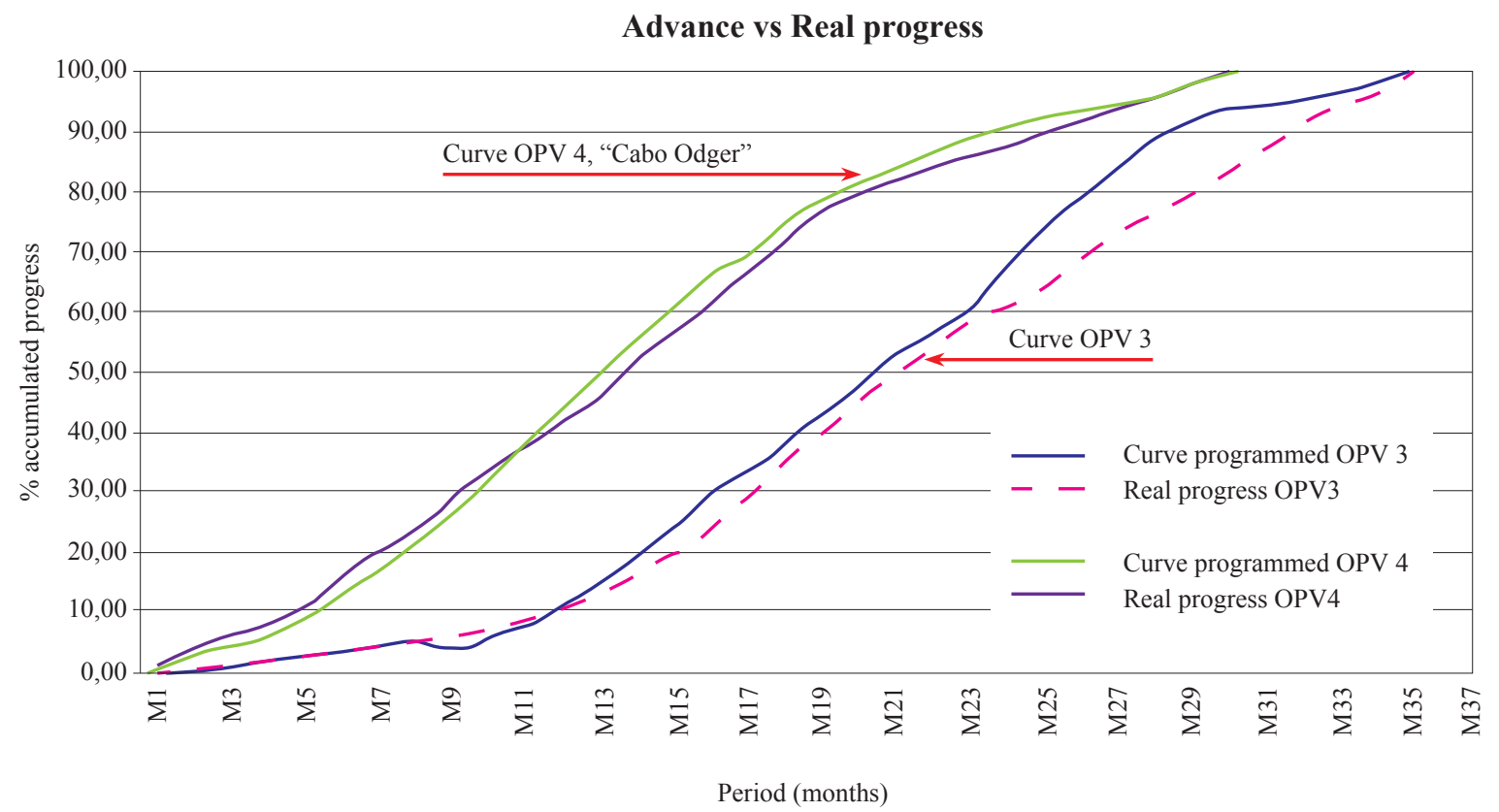


The inclusion of this Construction Strategy throughout the logistics and production chain must involve the entire organization of shipbuilding management and its dependent centers, as the participation of just one center can generate unexpected results.

The Construction Strategy has to look at everything. Through the personnel and the different tools it has available it is able to carry out the sequencing and logical integration of the works in different stages of assembly of the unit under construction.

It allows the development of pre-operation equipment at the panel level, proposing criteria for the assembly of these elements, with the aim of minimizing interference between the different workshops of the production department.

Clear evidence of a decrease in the programming time, and a greater efficiency in the processing of tasks by the dispatcher to the different productive fronts has been displayed.

A decrease in hot work has been achieved by avoiding redoing welding in finished spaces and reducing the risk of accidents to our collaborators.

The decentralization of the administration in the tasks and responsibilities in the project can be achieved as a consequence of the implementation of the knowledge management and the correct use of the information of the three axes or differentiating factors:
The Construction Strategy

Strategic Planning

Logistics

\section{References}

DEPARTMENT OF INFORMATION OF THE DIVISION OF INDUSTRIAL PRODUCTS AND TECHNOLOGY. (2011). Spain: Naval Construction Sector, sector notes ICEX. Spanish Institute of Foreign Trade (ICEX), 3.

TEAM OF PROFESSORS OF ESADE. (Marzo, 2014). Management guides for innovation, production and logistics. (C) Generalitat de Catalunya, Center for Innovation and Business Development (CIDEM), Barcelona

Gómez Senent Martínez, E. (1992). PROJECT PHASES AND ITS METHODOLOGY. SPUPV. Valencia

PALANCAR, P. L. (2008). 90 Years of naval and modular construction. Naval engineering (RIN), 74 - 91.

TRABA, D. J.-T., \& LÓPEZ, D. N. (2004/2006). Military Naval Construction, Ideas To Be A Leader. Madrid: XXVII Week of sea studies. 